\title{
MIGRASI DAN PROBLEMATIKA MINORITAS MUSLIM THAILAND
}

\section{Dian Ekawati}

Institut Agama Islam Negeri Metro Lampung azfadm01@gmail.com

\begin{abstract}
Migration is the movement of population from one area to another, whether from one village to other village or from one city to another city and from one country to other country conducted by someone or group of society with intention to stay and live or not, due to various factors as the reasons. Thailand is one of the country in Southeast Asian countries with its geographical location between Australian Continent and China's mainland. Muslims in Thailand are minority that develop rapidly and the biggest minority after China. They live in the southern part of Thailand as the base of Malay-Muslim communities, but it is a region that has religious conflict. Thai government obliges assimilation of Thai culture (Buddhism) towards Muslim minority. The struggle of Muslim Pattani society takes place for the their freedom in worship and conserves Pattani Malay culture.
\end{abstract}

Keywords: Migration, Cultural Assimilation, Minority Muslims 


\section{Abstrak}

Migrasi adalah perpindahan penduduk dari suatu wilayah ke wilayah lain baik itu dari desa ke desa lain, dari desa ke kota atau dari kota ke kota dan dari suatu negara ke negara lain yang dilakukan oleh seseorang atau sekelompok msyarakat dengan niat menetap atau tidak menetap karena berbagai faktor yang menjadi penyebabnya. Thailand adalah salah satu negara diantara negaranegara di kawasan Asia Tengara dengan letakgeografisnya berada di kawasan antara Benua Australia dan daratan China. Umat Islam di Thailand merupakan minoritas yang berkembang cepat dan merupakan minoritas terbesar setelah China, Mereka tinggal di kawasan Thailand bagian selatan sebagai basis masyarakat Melayu-Muslim namun merupakan daerah konflik agama. Pemerintah Thailand mewajibkan asimilasi budaya Thai (agama Budha) kepada muslim minoritas. Perjuangan masyarakat Muslim Pattani terjadi demi kebebasan mereka dalam beribadah dan melestarikan budaya Melayu Pattani.

Kata Kunci: Migrasi, Asimilasi Budaya, Muslim Minoritas 


\section{A. PENDAHULUAN}

$\mathrm{M}$ igrasi adalah perpindahan penduduk dari suatu wilayah ke wilayah tujuan dengan maksud menetap. Adapun migrasi sirkuler ialah gerak penduduk dari suatu tempat ke tempat lain tanpa ada maksud menetap. ${ }^{1}$ Migrasi adalah perpindahan penduduk dari desa ke kota, atau perpindahan penduduk atau kelompok orang dari suatu wilayah ke wilayah lain baik dengan tujuan menetap atau tidak menetap.

Migrasi dapat dibedakan pada beberapa jenis, yaitu:

1. Migrasi masuk (in migration)

2. Migrasi keluar (out migration)

3. Migrasi Neto ( net migration)

4. Migrasi bruto (gross migration)

5. Migrasi total (total Migration)

6. Migrasi internasional (International migration)

7. Migrasi semasa hidup (life time migration)

8. Migrasi parsial (partial migration)

9. Arus mugrasi (migration stream)

10. Urbanisasi (Urbanization)

11. Transmigrasi (Transmigration)

Migrasi masuk adalah perpindahan penduduk dari daerah asal ke daerah tujuan, sementara migrasi keluar ialah keluarnya penduduk dari daerah asalnya. Migrasi neto ialah selisih antara jumlah migrasi masuk dan migrasi keluar sedangkan migrasi bruto ialah jumlah migrasi masuk dan migrasi ke luar wilayah.

Migrasi total ialah seluruh kejadian migrasi, seperti migrasi seumur hidup, dan migrasi pulang. Migrasi internasional adalah perpindahan penduduk dari suatu negara ke negara lain, sementara migrasi semasa hidup ialah migrasi berdasarkan tempat kelahiran, yaitu bagi warga yang sewaktu penaccahan jiwa bertempat tinggal di daerah berbeda dari daerah tempat lahirnya.

Migrasi Parsial ialah jumlah migran ke suatu daerah tujuan dari satu daerah asal ke daerah asal ke satu daerah tujuan. Arus

1 Siti Soliah, "Pola Migrasi Masyarakat", Jurnal Migrasi, FKIP, UMP, 2016, h. 1. 
mugrasi adalah jumlah atau banyaknya perpindahan yang terjadi dari daerah asal ke aderah tujuan dalam jangka waktu tertentu.

Urbanisasi ialah bertambahnya proposisi penduduk yang berdiam di daerah kota yang disebabkan oleh proses perpindahan penduduk ke kota dan atau akibat dari perluasan kota. Sementara transmigrasi ialah perpindahan dan pemindahan penduduk dari suatu daerah untuk menetap ke daerah lain yang ditetapkan di dalam Republik Indonesia guna kepentingan pemerataan pembangunan negara atau karena alasan-alasan lain yang dianggap perlu dan berdasarkan undang-undang yang berlaku pada saat pelaksanaan trasmigrasi penduduk.

Lambannya proses perubahan status dari desa ke kota dan lambatnya perkembangan pembangunan di wilayah desa menyebabkan banyaknya terjadi migrasi dari desakekota. Perbedaan yang mencolok adalah perkembangan di bidang pembangunan dan perbedaan dalam mengakses media sosial sebagai sumber informasi juga sangat dirasakan dari kedua daerah ini. Desa dengan segala kesederhanaanya dan kota dengan segala kemeriahannya. Ini salah satu yang menarik pendatang untuk tinggal di kota dan meninggalkan desa asalnya.

Fenomena migrasi banyak terjadi di wilayah negara-negara berkembang, seperti halnya Indonesia. Migrasi yang sangat dominan di Indonesia adalah Transmigrasi/perpindahan penduduk dari wilayah yang padat penduduknya ke wilayah yang jarang penduduknya dengan tujuan pemerataan jumlah populasi di seluruh Indonesia dan Urbanisasi yaitu perpindahan penduduk dari desa ke kota.

Urbanisasi dilakukan karena alasan lebih banyak dikemukakan oleh para pelaku urbanisasi adalah faktor sosial-ekonomi dan mencari peningkatan penghasilan dengan tujuan peningkatan status sosial di masyarakat. Urbanisasi/migrasi dari desa ke kota banyak dilakukan terutama oleh warga yang ingin mencari pekerjaan di kota dengan iming-iming upah yang tinggi.

Glamournya ibu kota membuat sebagian besar pendududuk 
desa tertarik untuk mengadu nasib ke kota, dengan harapan hidup mereka menjadi lebih baik. Hal ini tentu sangat berkaitan dengan faktor ekonomi yang membuat masyarakat desa punya anganangan yang tinggi untuk hidup lebih baik di kota demi peningkatan status sosial mereka di masyarakatnya.

Namun tidaklah sama dirasakan oleh muslim yang mengadu nasib dengan bekerja di negara-negara non muslim dengan harapan dapat mengumpulkan banyak uang yang akan bisa dibawanya pulang ke negara asalnya masing-masing. Muslim ini akan mengalami diskriminasi dalam melaksanakan kewajiban mereka atau hubungan vertikal mereka kepada Allah Swt. Dipersulitnya tempat ibadah, minimnya waktu buat sholat dan susahnya mencari makanan yang halal adalah kendala yang harus dihadapi muslim yang akan mengadu nasibnya di negara-negara non muslim.

Akhir-akhir ini tenaga kerja Indonesia (TKI), khususnya tenaga kerja wanita (TKW), yang tergolong dalam pekerja migran mendapat sorotan dari berbagai pihak, bahkan terdapat jargon yang sering didengar,, TKI ku sayang, TKI ku malang. Seperti kasus Ruhiyati yang dihukum pancung di Saudi Arabia, kasus penganiayaan yang dialami oleh Nirmala Bonet, TKI asal Nusa Tenggara Timur di Malaysia (2004), kasus penyiksaan Sumiati, TKI asal Nusa Tenggara Barat di Arab Saudi (2010). ${ }^{2}$

Fenomena-fenomena diatas adalah contoh migrasi sirkuler karena faktor ekonomi yang berakhir penganiayaan karena diremehkan dan dianggap rendah karena rendahnya pendidkan yang dimiliki oleh TKW dan TKI ini. Seperti halnya kata pepatah, "meskipun hujan emas di negera orang tapi lebih baik hujan batu di negara sendiri”. Artinya walau iming-iming mengumpulkan uang lebih banyak didapatkan dari negera orang tapi lebih enak mengais rezeki di tanah air sendiri. Akan lebih terjaga faktor kemanan kita.

Proses migrasi yang terjadi di suatu negara (International Migration) dianggap sebagai suatu hal yang alamiah sebagai kegiatan penyaluran tenaga kerja dari daerah di sektor kerja

2 Atik Krustiyati, "Optimalisasi Perlindungan dan bantuan”, Jurnal Dinamika Hukum Pekerja Migran Melalui Promosi Konvensi Pekerja Migran Tahun 2000, Vol. 13, No.1, januari 2013, h. 1-2. 
modern di wilayah kota yang daya serapnya lebih tinggi. ${ }^{3}$

Fenomena perpindahan penduduk dari desa ke kota lambat laun menjadi semakin banyak peminatnya, sehingga menjadi suatu hal yang sudah tidak wajar lagi. Kepadatan penduduk di wilayah perkotaaan menjadi diluar batas normal. Kota menjadi berjubel dengan penduduk-penduduk baru, karena setiap tahun selalu bertambah penduduk baru yang ingin mengadu nasib ke kota. Motif ekonomi menjadi alasan utama terjadinya migrasi karena ketimpangan pemerataan pembangunan antara kota dan desa.

Kondisi yang sangat mendominsi perpindahan penduduk ini adalah adanya harapan untuk mendapatkan kehidupan yang layak dan pendapatan yang tinggi. Selain tidak meratanya pekerjaan dan penghasilan para petani di wilayah pedesaan menjadi pemicu terjadinya migrasi dari desa ke kota.

Faktor sosial-ekonomi yang rendah sehingga tidak mencukupi kebutuhan keluarga memotivasi seseorang ingin masuk ke daerah lain dengan tujuan memperbaiki kesejahteraan hidupnya dan kelurganya. Perbedaan tingkat upah pembayaran pekerja antara desa dan kota juga menjadi penyebab seseorang atau sekelompok orang melalukan migrasi

Iming-iming tingginya upah pekerja di kota juga menjadi faktor tujuan yang menyebabkan seseorang atau sekelompok orang melakukan mobilisasi. Harapan perubahan hidup yang lebih baik, perubahan kesejahteraan keluarga menjadi lebih baik merupakan motivasi yang sangat kuat bagi seseorang dalam melakukan migrasi.

Namun Bukan semata faktor ekonomi saja yang menjadi penyebab seseorang atau kelompok orang melakukan migrasi dari suatu wilayah ke wilayah lain Ada beberapa faktor juga menjadi penyebab terjadinya migrasi. Seperti faktor alam, faktor jarak, faktor keamanan seseorang atau sekelompok orang juga menjadi alasan terjadinya migrasi.

Faktor jarak yang lebih dekat di kota dengan tempat bekerja

3 Didit Purnomo, "Fenomena Migrasi Tenaga Kerja dan Perannya Bagi Pembangunan Daerah Asal: Studi Empiris di Kabupaten Wonogiri”, Jurnal Ekonomi Pembangunan, Vol.10, No.1, Juni 2009, h. 2. 
juga menyebabkan seseorang atau sekelompok orang berpindah ke kota. Ini tentu berkaitan dengan jarak tempuh antara tempat tinggal dan tempat bekerja dan faktor ketepatan waktu dalam bekerja.

Faktor alam perkotaan yang semuanya serba mewah, fasilitas yang komplit juga membuat seseorang atau sekelompok orang tergiur melakukan migrasi. Kemegahan dan keindahan, kelengkapan fasilitas, mudahnya mengakses media sosial dan tekhnologi yang serba canggih adalah pemicu banyaaknya pelaku migrasi ke kota semakin bertambah.

Faktor keamanan juga menjadi penyebab seseorang atau sekelompok orang melakukan migrasi. Daerah asal yang dirasa kurang menjamin keamanan dan kenyaman dalam aktivitas membuat munculnya kegiatan migrasi dengan tujuan mencari keamanan yang kebih baik di daerah tujuan. Seperti yang diasakan oleh muslim minoritas yang hidup di negara mayoritas non muslim dan kurang menerima keberadaaan muslim minoritas bahkan cenderung membenci dan berusaha mengusir muslim minoritas dari negara nya.

Terjadinya migrasi bagi komunitas masyarakat juga berdasarkan beberapa faktor yang melatar belakangi nya. Beberapa faktor itu diantaranya: faktor yang terjadi di wilayah asalnya, faktor-faktor yang ada di daerah tujuan, faktor yang menjadi penghambat dan faktor pribadi yang dialami oleh seseorang.

Faktor yang terjadi di wilayah asal seperti terjadinya bencana alam yang tidak memungkinkan seseorang tinggal kembali di daerahnya menjadi penyebab yang melatar belakangi tejadinya migrasi. Migrasi ini cenderung perpindahan dari daerah ke daerah lain yang lebih layak untuk ditinggali.

Faktor pribadi juga menjadi penyebab seseorang atau sekelompok orang/komunitas masyarakat melakukan migrasi. Seperti halanya yang terjadi pada muslim minoritas yang tinggal di suatu negara dengan mayoritas masyarakatnya non muslim. Biasanya faktor keamanan dan kenyamanan dalam beribadah yang 
kurang terjamin menjadi penyebab muslim minoritas merasa resah dan tidak nyaman sehingga komunitas ini melakukan migrasi ke daerah atau negara lain yang bisa menerima mereka dan keimanan mereka dengan baik.

Kurang diterimanya perbedaan keimanan dan cara beribadah kadangkala membuat komunitas muslim yang minoritas di negaranegara yang mayoritas penduduknya non muslim dikucilkan. Kurang diterima mayarakat, Bahkan tempat ibadahnya pun dipersulit dalam pembangunan nya.

Fenomena yang dialami oleh muslim minoritas di suatu negara memotivasi muslim minoritas melakukan migrasi atau mobilisasi baik menetap atau berpindah-pindah dari suatu wilayah ke wilayah lain. Faktor keamanan dan kenyamanan menjadi alasan utama sekelompok muslim melakukan nya. Hidup menjadi muslim minoritas ditengah masyarakat yang mayoritas non muslim biasanya akan mendapatkan perlakuan yang kurang baik dan kurang diterima keberadaan mereka. Muslim minoritas cenderung dikucilkan karena perbedaan ibadah dalam mengabdi kepada sang Pencipta. Mereka selalu berharap bahwa agama dan ibadah mereka bisa diterima seutuhnya.

Seperti yang terjadi dengan komunitas muslim di Perancis. Komunitas muslim di negara ini cenderung memisahkan diri dari kehidupan sosial di negara ini dikarenakan alasan perbedaan keimanan. Masyarakat barat cenderung mengasingkan komunitas muslim dengan alasan perbedaan biologis, ideologis dan kultural, selain warisan sejarah permusuhan antara Barat dan Islam. Keraguan terhadap keniscayaan berintegrasi tidak hanya akan semakin mengucilkan komunitas muslim, tetapi lebih buruk lagi, akan menyudutkan posisinya sehingga mudah menjadi kambing hitam bagi kegiatan-kegiatan melawan negara dan mengganggu masyarakat.

Timbulnya konflik dan tindak kekerasan pada daerah atau wilayah di suatu negara tidak bisa dilepaskan dari keterkaitan antara adanya perbedaan dan faktor kepentingan. Kepentingan 
menguasai dan dikuasai oleh dan dari kelompok mayoritas terhadap minoritas. Munculnya kepentingan untuk menjajah dari kelompok mayoritas kepada minoritas telah terjadi pada minoritas muslim di beberapa negara di dunia.

Kepentingan dari mayoritas non muslim menguasai segala aspek yang dimiliki oleh muslim minoritas atas dasar perbedaan cara beribadah, perbedaan tempat beribadah, perbedaan kitab suci dan perbedaan keyakinan berakibat munculnya konflik yang mengakibatkan terjadinya kekerasan atau peperangan sehingga mengakibatkan banyak korban jiwa berguguran.

Indonesia adalah contoh negara dengan ke-Bhinekaan baik dari agama bagi pemeluk-pemeluknya maupun keragaman etnis budaya. Ke-bhinekaan di Indonesia tidak menyebabkan negara Republik Indonesia menjadi terpecah belah. Persatuan dan kesatuan tetap bisa dicapai di negara ini. Kedamaian dan kebebasan bagi warganya memeluk agama dan menjalankan keyakinannya masing-masing tetap bisa dijalankan di negara ini.

Indonesia merupakan negara yang berpenduduk muslim terbesar di dunia. Indonesia meskipun berpenduduk muslim sebagai mayoritas, tetapi hak untuk bebas dalam berkeyakinan dan beragama sesungguhnya telah dijamin sepenuhnya dalam UndangUndang Dasaar 1945 pasal 28 E, Undang-Undang nomor 39 Tahun 1999 tentang hak asasi manusia dan Undang-Undang nomor 12 tahun 2005 tentang pengesahan International Covenan Civil and Politic Right. ${ }^{4}$

Tidak ada perpecahan dan penjajahan bagi kaum mayoritas kepada kaum minoritas di Indonesia, meskipun mayoritas masyarakatnya memeluk Islam. Tidak ada faktor kepentingan dari muslim sebagai mayoritas untuk menjajah dan memaksakan agama kepada non muslim sebagaai minoritas masyarakat. Tidak ada pemaksaan etnis suku untuk memaksakan budaya dan bahasanya kepada etnis suku lain yang berbeda budaya dan bahasa.

Segala bentuk gerakan yang ingin mencoba melawan

4 Ahmad Solikhin, "Islam, Negara, dan Perlindungan Hak-Hak Islam Minoritas", Journal Of Governance, Vol 1, No.2, Desember 2016 h. 43. 
pemerintah dan ingin menganggu stabilitas negara masih bisa diatasi. Kerukunan ibadah antar ummat beragama bisa disaksikan di negara ini. Berdampingan antara masjid dan gereja serta kenyamanan beribadah bagi pemeluknya bisa ditemui di Indonesia. Negara ini masih menjadi percontohan bagi negara lain dalam hal kerukunan antar ummat beragama, antar etnis suku dan antar budaya.

Komunitas muslim minoritas di Filipina juga mengalami konflik berkepanjangan di negaranya. Terbentuknya muslim minoritas di Filipina disebabkan karena sebagian kecil penduduknya beragama Islam, sekitar $10 \%$ saja penduduk Filipina yang menganut agama Islam, minoritas muslim Filipina tinggal di wilayah yang diangap zona berbahaya oleh pemerintah Filipina. ${ }^{5}$

Ketika muslim minoritas di suatu wilayah atau negara merasa kemanan mereka terancam, mereka akan melakukan mobilisasi ke wilayah atau bahkan ke negara lain yang mereka anggap lebih aman lebih menerima mereka dalam melaksanakan kewajiban mereka dalam beribadah.

Hal serupa juga terjadi dengan minoritas muslim di Thailand. Mayoritas penduduk Thailand beragama Budha, hanya sedikit yang beragama Islam dan Konghucu, Akan tetapi umat Islam di Thailand merupakan minoritas yang berkembang cepat dan merupakan minoritas terbesar setelah China. Kawasan Thailand selatan yang merupakan basis masyarakat melayu-muslim adalah daerah konflik agama dan persengketaan wilayah dengan latar belakang ras dan agama yang berkepanjangan. ${ }^{6}$

Migrasi internasional merupakan bagian integral dari globalisasi ditandai dengan semakin melebarnya, mendalamnya dan semakin cepatnya keterkaitan antara seluruh aspek kehidupan sosial kontemporer dunia. Migrasi Internasional difasilitasi oleh peningkatan berbagai arus lintas batas negara, termasuk informasi modern dan tekhnologi komunikasi. ${ }^{7}$

5 Lihat Rina Rehayati, "Minoritas muslim”, Jurnal Ushuludin, Vol. XVII, No. 2, Juli 2011, h. 226.

6 Faruq Junaidi, “Minoritas Muslim Thailand Selatan”, Artikel ilmiah, t.t., h. 2

7 Elisabeth Dewi, “Migrasi Internasional”, h. 5 
Migrasi muslim dunia terjadi lebih karena tidak diterimanya kehadiran mereka sebagai muslim di negara asal dengan mayoritas masyarakatnya non muslim. Diperangi, selalu terjadi konflik yang berkepanjangan membuat komunitas muslim yang tinggal di wilayah konflik melakukan migrasi/mobilisasi ke wilayah lain yang lebih aman dan mau menerima mereka dan menghormati agama yang mereka anut.

Hidup berdampingan dengan mereka dalam kehidupan masyarakat yang normal dan damai, saling menghormati agama masing-masing penduduk adalah harapan yang dimiliki setiap muslim minoritas di mana pun ia tinggal. Hidup bermasyarakat dan beragama dengan rukun dan damai tanpa adanya peperangan dan permusuhan adalah mimpi setiap muslim dan mereka berharap akan terjadi suatu saat nanti.

Rumusan-rumusan tentang hubungan muslim dan non muslim terutama dalam masyarakat/negara minoritas muslim memang belum dirumuskan oleh ulama-ulama pada masa lalu, karena ulama pada saat itu hidup di wilayah mayoritas muslim. ${ }^{8}$

Karena belum ada aturan atau kaidah yang mengatur pola kehidupan masyarakat minoritas muslim masa ulama terdahulu maka saat ini hendaknya dan pemerintah bekerja sama menciptakan suasana yang harmonis dan damai menjalin hubungan yang serasi antara muslim minoritas dan non muslim mayoritas.

Umat Islam minoritas hendaknya hendaknya diberikan kesempatan untuk menyampaikan ide dan gagasan tentang ajaran agamanya dan sebaiknya di tanggapi dengan cara yang bijaksana. Mereka dihargai pendapatnya dan dihormati kewajiban beribadahnya.

Kenyamanan beribadah dan bermasyarakat akan membuat muslim minoritas merasa diterima kehadirannya di tengah-tengah mayoritas non muslim sehingga dengan kenyamanan itu tidak akan memunculkan keinginan muslim minoritas untuk melakukan migrasi ke wilayah lain.

8 Abdul Wahib, "Pergulatan Pendidikan Agama Islam di Kawasan Minoritas Muslim", Jurrnal Walisongo, Vol.. 19, No.2, 2011, h. 6. 
Kenyamanan dan ketenteraman dalam bermasyarakat akan mengurangi konflik kehidupan sosial dalam suatu masyarakat dan mengurangi migrasi terjadi karena alasan tidak terjaminnya keamanan.

Sikap keras dan anarkis yang dilakukan oleh aparat keamanan pada muslim minoritas dengan mengawasi seluruh gerakgerik mereka dalam segala hal dengan penuh kecurigaan dan menganggap bahwa semua yang muslim lakukan adalah radikal dan ada kaitannya dengan terorisme, membuat muslim minoritas di negara itu menjadi sangat tertekan.

Dibatasi semua akses yang terhubung dengan dunia luar, diawasi semua kegiatan keagamaan, dilarang memperdengarkan adzan dengan pengeras suara, dilarang melaksanakan shalat berjamaah di masjid, dilarang menggunakan nama-nama muslim, dilarang menggunakan budaya mereka dan sebarek laranganlarangan lain adalah bentuk kedzaliman dan penjajahan pada hak asazi setiap manusia.

Hendaknya organisasi keamanan dunia (PBB) ikut berperan penting dalam mewujudkan perdamaian dari negara-negara dengan minoritas penduduknya beragama tertentu, yang tengah di landa konflik berkepanjangan. Mewujudkan stabilitas dunia dengan memberikan solusi terbaik tanpa memihak kepada salah satu dari kedua pihak yang tengah mengalami konflik berkepanjangan adalah tugas utama PBB.

Seolah-olah dunia akan murka jika muslim yang mayoritas berbuat tidak baik terhadap non muslim minoritas, tetapi dunia akan diam saja ketika muslim minoritas di dzolimi hak-hak nya dalam beragama dan bermasyarakat oleh masyarakat non muslim mayoritas.

Suatu lembaga dunia hendaknya bersikap adil kepada seluruh penduduk dunia apapun agamanya dan apapaun warna kulitnya. Semoga segera tercipta perdamaian dunia seperti yang kita citacitakan semua. 


\section{B. PENGERTIAN MIGRASI}

Migrasi adalah perpindahan penduduk dari suatu wilayah ke wilayah lain dengan tujuan menetap. Migrasi sirkuler ialah gerak penduduk dari suatu tempat ke tempat lain tanpa ada maksud untuk menetap. Migasi sirkuler dapat terjadi antara desa ke desa, desa ke kota dan kota ke kota.

Migrasi sebagai perpindahan penduduk dengan tujuan untuk menetap dari satu tenpat ke tempat lain melampaui batas politik/ negara ataupun batas administrasif atau batas bagian suatu negara. Migrasi adalah bentuk respon yang ada dalam diri manusia terhadap kondisi/peristiwa yang tidak menyenangkan di daerah asal, seperti halnya dengan system pemilikan tanah yang tidak sama sekali menguntungkan.

Dari beberapa pendapat diatas bisa disimpukan migrasi adalah perpindahan penduduk dari suatu wilayah ke wilayah lain baik itu dari desa ke desa lain, dari desa ke kota atau dari kota ke kota dan dari suatu negara ke negara lain yang dilakukan oleh seseorang atau sekelompok msyarakat dengan niat menetap atau tidak menetap karena berbagai faktor yang menjadi penyebabnya.

Migrasi muslim minoritas ialah perpindahan/mobilisasi komunitas muslim dari suatu wilayah ke wilayah lain atau dari suatu negara ke negara lain dengan tujuan mendapatkan jaminan keamanan dalam hidup dan jaminan keamanan dalam menjalankan kewajiban beribadah kepada Allah SWT.

Menjadi komunitas muslim minoritas di tengah masyarakat yang mayoritas non muslim memang menjadi masalah tersendiri. Perbedaan keimanan dan cara beribadah menyebabkan muslim minoritas di beberapa negara kurang diterima keberadaanya. Mereka cenderung di kucilkan dan dijauhi. Mereka kurang diterima oleh masyarakat mayoritas karena perbedaan agama. Perbedaan keimanan dan cara beribadah, perbedaan tempat ibadah membuat muslim minoritas selalu dikucilkan. Bahkan di beberapa negara, muslim minoritas dimusuhi dan diperangi. 
Begitu juga yang terjadi dengan muslim minoritas di negara Thailand. Keberadaan muslim minoritas di negara berbentuk kerajaan ini kurang diterima oleh masyarakat mayoritas non muslim. Muslim di negara ini selalu dimusuhi dan dikucilkan. Segala akses dipersulit bagi muslim di negara ini. Hal ini bermula dari bertahannya muslim dengan wilayah kerajaan melayu muslim yang menjadi basis utama berkembangnya muslim di Thailand. Namun pemerintahan Thailand (kerajaan Siam) menghapus keberadaan melayu dan menguasai adat istiadat melayu muslim. Persengketaan masuh tetap terjajdi sampai saat ini.

Islam di Thailand banyak dijumpai di beberapa provinsi wilayah selatan negeri gajah putih ini, antara lain provinsi Pattani (80\%), Yala (68,9\%), Narathiwat, Satun (67,8\%), Songkhla, seluruh wilayah tersebut dulunya masuk wilayah kerajaan Pattani Raya pada abad ke-12, sebelum kerajaan Sukhotai berdiri.

Thailand dengan julukannya negeri gajah putih adalah sebuah negara berbentuk kerajaan yang mayoritas penduduknya memeluk agama Budha. Namun saat ini, kerajaan Thailand cukup mensupport kehidupan Islam untuk penduduknya. Seseorang yang di panggil Mufti adalah seseorang yang ditunjuk pemerintah di Thailand sebagai penanggung jawab masalah-masalah yang berhubungan dengan agama Islam di Thailand. Mufti mendapatkan gelar Syaikhul Islam (Chularajmontree). Mufti bekerja di bawah naungan Kementerian dalam negeri dan kementerian pendidikan yang betanggung jawab kepada raja. Mufti bekerja mengurusi semua yang berhubungan dengan muslim Thailand dengan jumlah mencapai 4,6\% atau sekitar 4 juta dari 65 juta jiwa total penduduk Thailand.

\section{PROBLEMATIKA MINORITAS MUSLIM PATTANI THAILAND SELATAN}

Minoritas adalah kelompokorangyang sejarahnya tidak tertulis, kondisi keberadaanya tidak dikenal, cita-cita dan aspirasinya tidak diapresiasi. ${ }^{9}$

9 Rina Rehayati, “Minoritas Muslim”, Jurnal Ushuluddin, Vol XVII No.2 Juli 2011, h.1 
Masyarakat Asia tenggara juga di kenal sebagai masyarakat muslim melayu. Sebagaimana dikutip dari Azyumardi Azra bahwa masyarakat Asia Tenggara juga dikatagorikan sebagai wilayah kebudayaan yang cukup berpengaruh dari tujuh wilayah kebudayaan dunia, seperti kebudayaan Arab yang mencakup semenanjung Arabia dan daerah-daerah Madrid, Afrika Utara dan lainnya.

Menilik sejarah adanya muslim minoritas di Thailand. Melayu muslim adalah etnis pribumi yang mendiami Pattani, salah satu provinsi di wilayah perbatasan selatan negara Thailand. Identitas ini terbentuk sebagai akibat asimilasi antara Islam di satu sisi dan melayu di sisi yang lain.

Islam dan kebudayaan melayu menyatu dan tidak terpisahkan. Bagi masyarakat Pattani, menjadi muslim tidaklah cukup, tetapi syarat kesempurnaannya sebagai muslim adalah menjadi melayu. Assimilasi inilah yang membentuk identitas sekaligus karakter etnisitas muslim di wilayah Pattani yang membedakannya dengan komunitas muslim lainnya di wilayah Thailand. ${ }^{10}$ Minoritas adalah sekelompok orang yang karena satu dan lain hal menjadi korban pertama despotisme negara atau komunitas yang membentuk mayoritas. Mereka adalah orang yang sejarahnya tetap, tidak tertulis, kondisi keberadaanya tidak dikenal, cita-cita dan aspirasinya tidak diapresiasi. ${ }^{11}$

Suatu negara yang yang penduduknya terdiri dari mayoritas muslim ternyata bisa juga menjadi minoritas karena dikuasai oeleh non muslim. ${ }^{12}$

Umat Islam di Thailand merupakan minoritas yang berkembang cepat dan merupakan minoritas terbesar setelah China. Seperti halnya kaum minoritas di negara-negara lain, kawasan Thailand bagian Selatan yang merupakan basis masyarakat Melayu-Muslim adalah daerah konflik agama. Selain itu terjadi persengketaan Wilayah karena latar belakang ras dan agama yang berkepanjangan. ${ }^{13}$

10 Ali Sodiqin, "Budaya Muslim Pattani (Integrasi Konflik daan Dinamikanya)", Jurnal Kebudayaan Islam, Vol.14, No.1 Januari-Juni, h. 2016, h. 32.

11 Rina Rehayati, “Minoritas muslim”, Jurnal Ushuludin, Vol. XVII, No. 2, Juli 2011

12 Rina Rehayati, "Minoritas muslim", h. 4.

13 Niaripen Wayeeka, "BerIslam dan Bernegara Bagi Muslim Patani: Perspektif Politik 
Thailand adalah salah satu negara diantara negara-negara di kawasan Asia Tengara. Secara geografis, kawasan Asia Tenggara merupakan kawasan antara Benua Australia dan daratan China. Dengan letak geografis Thailand membuat negara yang dijuluki dengan Gajah Putih ini mudah dijangkau oleh para turis dari berbagai penjuru negara. Mayorits penduduk Thailand beragama Budha., sedikit yang beragama Islam dan Konghucu.

Thailand sebagaimana penjelasan sebelumnya adalah suatu negara berbentuk dengan penduduknya mayoritas beragama Budha aliran Theravada dan sebagian kecil lainnya beragama Islam serta Konghucu. Agama Budha ditetapkan sebagai agama resmi negara. Islam adalah agama minoritas di negara Thailand. Masyarakat muslim di Thailand pada umumnya tinggal diwilayah selatan Thailand khususnya provinsi Pattani, Yala, Narathiwat, sebagian Satun dan Songkhla. Sebagaimana kondisi masyarakat minoritas pada umumnya

Masyarakat Melayu Muslim di Thailand sering mendapatkan tindakan diskriminasi dalam berbagai aspek kehidupan. Salah satu bentuk diskriminasi terberat yang dialami oleh minoritas Melayu Muslim di Thailand adalah kebijakan asimilasi budaya yang diterapkan secara paksa oleh pemerintah Thailand sejak rezim Jenderal Phibul Songkhram, dimana dalam kebijakan tersebut Thai Budha ditetapkan sebagai identitas dan budaya tunggal Thailand. Kebijakan pemerintah Thailand tentang asimilasi budaya adalah bentuk nyata bahwa Thailand ingin menghapus kultur melayu muslim dan digantikan dengan budaya Thailand di seluruh wilayah Thailand. Dalam kebijakan tersebut terdapat larangan penggunaan nama, bahasa dan Islam lainnya dalam kehidupan masyarakat.

Untuk bisa bekerja di lembaga pemerintahan, identitas dari melayu muslim sangat didiskriminasikan. Hal itu membuat muslim di Thailand menjadi tertekan dan terbatasi kebebasan mereka dalam bermasyarakat. Pemerintah Thailand membuat pandangan bahwa muslim melayu merupakan kelompok kriminal yang berbahaya bagi masyarakat. Stigma itu akhirnya membuat etnis

Profetik", Jurnal Agama dan hak Asasi Manusia, Vol. 5, No.2, Mei, 2016, h. 2. 
asli Thai selalu merasa curiga dengan segala gerak laku muslim melayu Thailand. Kebijakan asimilasi budaya juga mengharuskan melayu muslim Thailand meninggalkan budaya melayunya dengan budaya dan identitas Budha Thailand.

Kedudukan budaya Pattani yang minoritas menjadikan posisinya selalu tersubordinasi oleh budaya Thai yang mayoritas. Dengan kekuatan politik dan militernya, pemerintah Thailand gencar mengeluarkan kebijakan asimilasi, baik melalui jalur pendidikan, politik, budaya, maupun hukum. Dengan mendasarkan diri pada ideologi "nation, king, and religion", dikembangkanlah nation building yang bertujuan menundukkan semua komponen warga negara ke dalam satu nasionalisme, yaitu Thai Ideologi nasionalismeini ideologi, antara nasionalisme Thailand (Thai-Buddha) dengan nasionalisme Pattani (MelayuMuslim). Masyarakat Pattani memaknai bahwa setiap upaya integrasi/asimilasi pemerintah merupakan upaya dekulturisasi atas kebudayaan Muslim-Melayu. Mempertahankan dan menjaga identitas bagi masyakarat Pattani adalah sebuah jihad keagamaan.

Aspek penting dalam kebudayaan Melayu Muslim Pattaniadalah hukum Islam. Kedatangan bangsa Thai mengubah peta jurisdiksi hukum Islam di wilayah ini. Pemerintah Thailand melakukan intervensi dalam sistem hukum, dengan memberlakukan hukum sipil Thailand pada masyarakat Pattani dan menggeser kedudukan hukum Islam. Melalui serangkaian perjuangan, pada akhirnya ditetapkanlah Kitab Hukum Keluarga Islam dan Kewarisan Islam yang berlaku khusus di wilayah provinsi selatan, yang meliputi Pattani, Narathiwat, Yala, dan Satun. Intervensi sistem hukum ini juga diikuti dengan pembatasan kewenangan penegak hukumnya, Dato' Yuthithams, yang perkara pernikahan, perceraian, dan kewarisan Islam. Peradilan Islam juga digabungkan dalam peradilan sipil. Intervensi dalam pelembagaan hukum Islam dan bagaimana respon masyarakat Melayu Muslim. ${ }^{14}$

Hingga saat ini, minoritas Melayu Muslim Thailand

14 Lihat pula Ali Sodiqin, "Budaya Muslim Pattani (Integrasi Konflik daan Dinamikanya)", Jurnal Kebudayaan Islam, Vol.14, No.1 Januari-Juni 2016, h. 33. 
khususnya wilayah selatan masih terus merasakan diskriminasi dari pemerintah Thailand. Kehidupan sosial politik mereka pun menjadi terbelenggu dalam ketidak-bebasan. Kebebasan bersuara, berpendapat dan melaksanakan budaya melayu pun terkekang dalam tekanan. Kondisi ini benar-benar membuat melayu muslim Thailand benar-benar tidak nyaman dalam kehidupannya.

Dalam kaitannya dengan masyarakat Muslim Thailand, pemerintah Thailand Thai Budha menerapkan kebijakan asimilasi budaya yang sangat mengekang kebebasan hidup masyarakat Muslim Thailand. Kebijakan tersebut secara garis besar berisi tentang keputusan pemerintahan Thailand menjadikan Thai Budha sebagai identitas dan kebudayaan tunggal negara. ${ }^{15}$

Awal mulanya Islam di Thailand dimulai dari abad ke12, dimana Islam mulai masuk di daerah Pattani. Awal masuknya ke Pattani dimulai sejak kerajaan Siam menguasai kerajaan Pattani Raya/ pattani Darussalam. Pada tahun 1902 kerajaan Melayu dihapuskan. Penghapusan kerajaan Melayu di Thailand bagian selatan membuat melayu Pattani menjadi sangat tertekan. Khususnya pada pemerintahan Pibul Songgran (1939-1944), masyarakat melayu di Thailand selatan telah menjadi mangsa dasar asimilasi kebudayaan. Bahkan sampai saat ini masyarakat muslim minoritas Pattani Thailand masih menghadapi diskriminasi komplek dan terror terus-menerus. Kehidupan sosial maupun politik muslim Pattani menjadi terbatas.

Nik Anuar mengatakan" Sengketa di perbatasan negeri berlaku di merata dunia sepanjang masa. Bukan sedikit tentera dan orang awan terkorban sebelum bukit Golan jatuh ke tangan Israel, India dan Pakistan berbalah hingga ke saat ini bagi mengesahkan hak ke atas Kashmir. Demikian juga halnya dengan isu Pattani Mindanao, Aceh, Timor Timur, Pulau batu Putih, Pulau Layang-Layang, Spartly yang strategic bagi dan dikatakan sarat dengan petroleum di perut buminya, tapak Masjid Babri kerana sentiment agama terdahulusemua ini menjadialasan bagi sengketa, perbalahan dan perebutan. ${ }^{16}$

15 Bayu Mitra Adhiyatama Kusuma, “Masyarakat Muslim Thailand Dan Dampak Psikologis kebijakan asimilasi Budaya”, Jurnal Hisbah, Vol.13, No.1 Juni, 2016, h. 4.

16 Faruq Junaidi, “Minoritas Muslim Thailand selatan”, Artikel Ilmiah, t.t., Faruq Junaidi, 
Ini adalah gambaran bagaimana persengkataan karena perebutan wilayah di Thailand bagian selatan masih saja terus terjadi. Muslim minoritas Pattani akan tetap mempertahankan wllayah mereka yang dulunya merupakan kerajaan Melayu di Thailand Selatan. Persengketaan terjadi karena dihapusnya kerajaan Melayu di negara gajah putih ini Jika melayu sebagai penganut Islam hilang dari negara ini, berarti Islam juga hilang. Islam dan pemeluknya akan hilang dari negara gajah putih ini. dengan kata lain, pemerintah Thailand ingin menghapuskan penduduk melayunya yang beragama Islam.

Konflik berkepanjangan yang melibatkan kelompok minoritas muslim di kawasan Asia Tenggara sebenarnya bukan hanya terjadi di Thailand, namun juga di Filipina. Namun di Filipina selatan konflik sudah mulai reda ketika presiden Beniqno Aquino mengajukan proposal legislasi kepada parlemen Filipina dan mayoritas penduduk Thailand yang beragama Budha, untuk mensahkan kebijakan pemberian otonomi lokal khusus kepada muslim Moro Filipina, tidak beda dengan mayoritas penduduk Thailand yang beragama Budha. Sedangkan di Thailand sampai saat komunitas melayu muslim masih terus mengalami diskriminasi yang komplek serta terror hingga sekarang. ${ }^{17}$

Sejarah masuknya Islam ke Thailand dikemukakan oleh Azyumardi Azra dalam Ensiklopedi Tematis Dunia Islam, Asia Tenggara, bahwa Islam masuk ke Thailand diperkirakan pada abad ke-10 atau ke-11 di kawasan Thailand selatan atau tepatnya di daerah Pattani. Islampun masuk ke daerah kerajaan Pattani melalui pedagang-pedagang dari Arab dan India. Karena daerah Pattani merupakan daerah yang maju dan strategis untuk disinggahi. Yang mana mereka disebut sebagai Islam atau orang muslim sebelum kerajaan Siam (Thailand) dibentuk. ${ }^{18}$

Pattani merupakan kerajaan terletak di sebelah selatan Thailand dengan penduduknya melayu dan dipimpin oleh seorang raja Minoritas Muslim Thailand selatan, Artikel Ilmiah, t.t., h. 1.

17 Bayu Mitha Adhyatama Kusuma, "Masyarakat Muslim Thailand dan Dampak psikologis Kebijakan asimilasi Budaya”, Jurnal Hisbah,, Vol.13, No.1 Juni 2016, h. 2.

18 Faruq Junaidi, “Minoritas Muslim Thailand selatan”, Artikel Ilmiah, t.t., h. 2. 
yang bernama Sulaiman. Kerajaan Siam waktu itu berusaha ingin menguasai Pattani dengan mengirimkan berulang kali pasukan untuk merebut wilayah Pattani, namun usaha nya selalu gagal.

Masa kejayaan kerajaan Pattani ialah ketika dipimpin oleh raja Muzhaffar, dapat mengalahkan keserakahan Siam yang ingin berusaha merebut Pattani. Ini awal mula kaum muslim Pattani melakukan pemberontakan kepada Kerajaan Siam (Thailand) dan berkeinginan melepaskan diri dari kekuasaan Thailand. Pemberontakan terjadi karena Siam/Thailand bersikap keras dan melakukan tekanan terhadap minoritas muslim serta memerintahkan mengganti nama mereka menjadi Thailand serta menguasai adat istiadatnya.

Muslim melayu Pattani tidak mau kalah dan tetap melakukan pemberontakan demi mempertahankan wilayah melayu mereka. Bertahan demi wilayah dan agama mereka. Bahkan muslim Pattani sudah memiliki Universitas Islam terbesar di negara Thailand. Pattani bisa dikatakan bernasib sama dengan muslim di Palestina Timur Tengah. Jika muslim Palestina dijajah oleh Israel, maka muslim Pattani dijajah oleh Thailand.

Berawal pada tahun 1875 Thailand datang ke wilayah Pattani dan menguasai wilayah Pattani. Bersamaan dengan datangnya Inggris ke wilayah semenanjung Malaka. Pertemuan Thailand dan Inggris menghasilkan perjanjian baahwa Pattani dikuasai Thailand sementara daerah Perlis dan sekitarnya di kuasai oleh Inggris. Inggris kemudian menyebut wilayah jajahan nya dengan nama Malaysia. Muslim Pattani dipaksa untuk tunduk dan patuh menjadi bagian dari Siam/Thailand, namun muslim Pattani terus menolak dan memberontak hingga sekarang.

Dalam perjuangan mempertahankan wilayah, bermunculan 3 kelompok yang dipelopori oleh tokoh ulama pejuang Pattani. Tokoh ulama pertama memperjuangkan kemerdekaan Pattani dengan ciri-ciri pergerakannya: menitik beratkan pada ajaran yang mengandung arti jihad dan menolak pembangunan dari pemerintah Thailand. Ulama ini sangat menghormati tokoh-tokoh 
dunia seperti tokoh Indonesia yang sudah diakui oleh dunia tentang perjuangannya yaitu Ir. Soekarno.

Berbeda dengan pergerakan perjuangan dari tokoh ulama yang kedua. Ulama kedua ini mempunyai cri-ciri pergerakan: mendukung pemerintahan Thailand karena mereka merasa tidak ditindas atau dijajah oleh pemerintahan Thailand, karena di Thailand dibebaskan masyarakatnya menganut agama apapun. Kelompokm ulama yang kedua ini memilih untuk mendukung dan membantu segala bentuk pembangunan yang dilaksanakan oleh pemerintahan Thailand di propinsi Pattani. Kelompok ini berpandangan seperti muslim di Indonesia bahwa Islam cinta perdamaian, dan menghindari segala bentuk konflik dan permusuhan.

Kelompok ulama ketiga berbeda lagi dengan kelompok ulama pertama dan kedua. Kelompok ulama ini memilih berada diantara kelompok pertama dan kedua. Kelompok ini akan bereaksi melakukan perlawanan terhadap pemerintahan Thailand jika terjadi penganiayaan terhadap kaum muslimin di sana. Tapi jika muslim di Thailand hidup damai tanpa pengaaniayaaan maka kelompok ini akan diam dan tidak melakukan gerakan apapun. Ciri perjuangan kelompok ketiga ini adalah dengan sembunyi-sembunyi underground.

Permasalahan yang dialami oleh muslim Pattani yaitu berupa tekanan dan dan hidup mencekam dalam bayang-bayang pemerintahan Thailand sudah berlangsung lama. Banyak terjadi pertumpahan darah di tanah Pattani. Kerukunan antar agama jarang terlihat. Pemerintahan Thailand melarang penyimpanan buku-buku karya warga Pattani. Cerita sejarah melayu Pattani dihilangkan oleh pemerintah, Warga pattani dilarang berbicara dengan bahasa Melayu. Bahasa sehari-hari yang dipakai, bahasa pengantar di sekolah dan nama-nama yang mereka pakai sebagai identitas haruslah dipakai dengan bahasa dan nama Thailand (bahasa dari agama Budha yang berasal dari kerajaan Siam). Kondisi yang diciptakan pun selalu menegangkan karena setiap sudut jalan selalu dijaga oleh tentara berseragam militer lengkap dengan senjatanya. 
Bangsa Thai yang beragama Budha banyak menyadur kebudayaan muslim Pattani, mulai dari bidang politik, budaya, hukum dan pendidikan. Jalur politik dilakukan dengan pendekatan nasionalisme, raja, dan agama. Thailand mewajibkan seluruh warga tunduk dalam satu nasionalisme. Sementara pendekatan di bidang pendidikan dengan memasukkan ajaran Thai, dan Budha serta bahasa Thai dalam proses pendidikan.

Gerakan perlawanan bangsa melayu Pattani pertamakali muncul sebagai sebuah gerakan damai yang memperjuangkan otonomi bagi pattani. Gerakan perlawanan yang muncul dipahami sebagai salah satu upaya mempertahankan identitas nilai keagamaan dan etnisitas mereka dengan menuntut diberhentikannya sikap diskriminatif kerajaan Thai.

Kedudukan budaya pattani yang minoritas menjadikan posisinya selalu tersubordinasi oleh budaya Thai yang mayoritas. Dengan kekuatan militer dan politiknya, pemerintah Thailand gencar mengeluarkan kebijakan asimilasi, baik melalui jalur pendidikan, politik, budaya maupun hukum. ${ }^{19}$

Muslim Pattani berfaham bahwa mempertahankan dan melestarikan budaya Pattani adalah jihad keagamaan. Kebudayaan muslim Pattani berdasarkan hukum Islam. Sementara pemerintah Thailand memberlakukan hukum sipil Thailand pada masyarakat Pattani. Hukum ini tentu saja menggeser hukum Islam yang diterapkan di Pattani. Namun dengan perjuangan yang panjang akhirnya diresmikan buku pedoman dalam hukum keluarga dan kewarisan Islam berlaku di wilayah provinsi selatan yang meliputi Pattani, Narathiwat Yala dan Satun.

Negara Thailand terdiri dari 77 provinsi dengan jumlah penduduk 67 juta jiwa. Patani menjadi salah satu dari lima wilayah di Thailand selatan selain, Yala, Narathiwat, Satun (Setul) dan Songkhla, Mayoritas dihuni oleh umat Islam. Jumlah penduduk Muslim di Thailand sekitar 15 persen dibandingkan penganut Budha yang 80 persen. Mayoritas muslim tinggal di Selatan Thailand

19 Ali Sodiqin, "Budaya Muslim Pattani (Integrasi Konflik daan Dinamikanya)", Jurnal Kebudayaan Islam, Vol.14, No.1 Januari-Juni 2016, h. 32. 
sekitar 1,673,900 juta jiwa, atau 80 persen dari total penduduk khususnya di provinsi Patani, Yala, Naruthiwat, tiga provinsi. Tradisi wilayah Asia Tenggara, termasuk Thailand selatan. ${ }^{20}$

Negara Pattani memiliki sejarah sangat panjang melebihi negara-negara lain seperti Malaka, Selangor dan Johor. Sejarah lama negeri Pattani banyak dipengaruhi oleh Kerajaan Melayu Tua pengaruh Hindu-India yang bernama Langkasuka.

Wilayah timur Langkasuka terdiri dari daerah pantai timur semenanjung, dari daerah Senggora, Pattani, Kelantan, Trengganu, termasuk juga wilayah utara negeri Kedah. Catatan sejarah menjelaskan bahwa Langkasuka adalah wilayah Pattani sekarang.

Cerita sejarah yang menjelaskan bahwa kerajaan Pattani berasal dari kerajaan Melayu yang pusatnya di daerah pedalaman yang sukar di jangkau masyarakat luar dan para pedangang. Kemudian Raja Pattani mempunyai ide dan menjalankan idenya untuk memindahkan pusat kerajaan Pattani ke sebuah perkampungan nelayan, sehingga wilayah ini mudah dijangkau oleh pendatang dan para pedagang. Perkampungan nelayan ini kemudian diberi nama "Pattani"

Berjalan nya waktu, karena letak geografisnya yang strategis, maka wilayah Pattani menjadi tempat utama para pedagang dari wilayah timur maupun barat dalam berniaga. Maka berkembanglah Pattani menjadi pusat perdagangan di Thailand pada masa itu.

Menurut ahli Antropologi, orang Patani berasal dari suku Jawa Melayu. Karena suku inilah yang pertama kali mendiami tanah Melayu. Kemudian berdatangan pedagang Arab dan India ke daerah Patani. ${ }^{21}$ Islam masuk ke Pattani melalui jalur perdagangan. Pattani menjadi negara Islam diperkirakan sekitar tahun $1457 \mathrm{M}$.

Sebuah cerita tertulis bahwa awal nya Pattani dipimpin oleh seorang raja yang bernama Phya Tu Nakpa. Raja menderita sakit yang tak kunjung sembuh, kemudian raja diobati oleh seorang

20 Niarepen Wayeekao, "BerIslam dan Bernegara Bagi Muslim Pattani: Perspektif Politik Profetik", Jurnal Agama dan Hak Azasi Manusia, Vol,5, No.2, Mei, 2016, h. 4.

21 Niarepen Wayeekao, "BerIslam Dan Bernegara Bagi Muslim Pattani: Perspektif Politik Profetik”, Jurnal Agama dan Hak Azasi Manusia, Vol,5, No.2, Mei, 2016, h. 3. 
tabib muslim. Selama tiga kali raja sakit dan tiga kali pula raja diobati oleh tabib yang sama dan sembuh. Akhirnya raja masuk Islam dan meninggalkan agama Budha yang semula dianutnya. Raja kemudian berganti nama menjadi Sultan Ismail Shah.

Agama Islam mengalami perkembangan yang sangat pesat di wilayah Pattani. Agama Budha mulai ditinggalkan yang pada akhirnya sama sekali tidak lagi dianut oleh melayu Pattani. Daerah Pattani awalnya bukanlah wilayah dari Thailand (kerajaan Siam), tetapi wilayah Islam di selatan Thailand. Ketika sultan ismail wafat, maka kepemimpinannya digantikan oleh putra mahkota yaitu Sultan Muzaffar Syah.

Pattani mencapai puncak keemasannya pada zaman ratu empat yaitu: Ratu Hijau (1584-1616 H), Ratu Biru (1616- 1624), Ratu Ungu (1624-1635), dan Ratu Kuning (1635- 1651). Kejayaan Pattani mulai menurun setelah Ratu kuning meninggal dunia pada tahun 1651. Kemunduran kerajaan dirasakan di bidang ekonomi, politik dan militer. Wilayahnya mulai memisahkan diri satu persatu dari Patani, seperti Kelantan, Terengganu, Pattani awal, Senggora, dan Pethalung.

Pattani di taklukkan oleh Siam (Thailand) pada tahun 1785 hingga sekarang. Inilah awal mula munculnya konflik di wilayah Pattani. Wilayah Pattani, Yala dan Narathiwat memiliki kebudayaan melayu Islam, jauh berbeda dengan budaya Thailand yang beragama Budha secara mayoritas masyarakatnya.

Perkiraan tahun 1930, pemerintahan Thailand melakukan perubahan sistem pemerintahan. Monarkhi absolut diganti menjadi monarkhi parlementer. Parlemen didominasi oleh tokoh-tokoh dari kalangan militer. Pergantian pemerintahan ini menyebabkan kebijakan pemerintahan pusat terhadap provinsiprovinsi di wilayah selatan Thailand yang berbasis Islam menjadi semakin radikal. Diskriminasi semakin Nampak dengan munculnya peraturan-peraturan lokal seperti, mewajibkan masyarakat Thailand Selatan menggunakan bahasa dan aksara thai, mengganti bahasa melayu dengan bahasa Thai, dan meninggalkan budaya 
melayu dengan budaya Thai yang sarat dengan nuansa Budha. Hal ini tentu sangat bertentangan dengan hati dan jiwa masyarakat selatan muslim yang beragama Islam.

Perlawanan pun akhirnya terjadi. Pattani dan wilayah muslim yang lain berusaha melepaskan diri dari kekangan dan tekanan pemerintahan Thailand. Perlawanan dan konflik yang terjadi bukan hanya disebabkan sebagai perlawanan antar kelompok agama, tetapi karena faktor kesenjangan sosial, politik, perlakuan kasar aparat keamanan terhadap muslim minoritas Thailand, faktor ekonomi dan diskriminasi sosial adalah pemicu lain munculnya perlawanan.

Gerakan bersenjata yang dipelopori oleh ustadz haji abdul Somad kariim hasan yang bernama gerakan Barisan Revolusi Nasional (BRN) berideologi Islam melakukan pemberontakan. Gerakan mereka menarik masyarakat Pattani untuk ikut bergabung. selain bergerak di bidang militer, gerakan ini juga bergerak di bidang sosial, pendidikan, dengan tujuan meningkatkan kesejahteraan masyarakat.

Pada tahun 2001 gerakan bersenjata BRN dibubarkan oleh pemerintah Thailand. Pada tahun yang sama juga gerakan pemberontakan besar pun terjadi. Dari tahun ke tahun pemberontakan dan penyerangan ke wilayah Thailand Selatan semakin bertambah. Setiap tahun kasus pemberontakan yang menewaskan aparat sipil semakin meningkat.

Pada April 2004 terjadi penyerangan aparat militer negara ke pasukan muslim pemberontak. Pengejaran terjadi hingga pemberontak muslim bersembunyi di sebuah masjid yang dianggap suci oleh masyarakat muslim wilayah selatan. Mereka ditembaki hingga tewas. Hal itu membuat masyarkat muslim di sana menjadi marah. Dari peristiwa itu mulai munculnya anggapan bahwa ada hubungan antara pejuang dengan Islam garis keras dan istilah jihad.

Organisasi pergerakan Islam mulai bangkit pada tahun 2005. Gerakan itu muncul dengan tujuan pembebasan Pattani dari cengkraman Thailand. Konflik terus terjadi dan memakan banyak 
korban jiwa. Masyarakat pun jauh dari kata aman dan nyaman dalam melangsungkan rantai kehidupan.

Pemerintah Thailand sudah berusaha untuk menghentikan pemberontakan dengan memberikan ketegasan pada para pemberontak di wilayah selatan negara mereka. Bentuk kerjasama dengan negara adikuasa (Amerika Serikat) pun dilaksanakan demi mendapatkan dukungan internasional dalam memberantas para pemberontak di Thailand. Tetapi konflik masih terus terjadi hingga saat ini.

Melayu pattani tetap berusaha mempertahankan budaya melayu benuansa Islami adalah identitas tersendiri bagi mereka. Asimilasibudaya Thai adalah usaha menghilangkan identitas melayu yang mereka miliki. Muslim Pattani akan tetap memperjuangkan identitas yang mereka miliki dengan penuh perjuangan. Kebebasan kembali dalam menjalankan kehidupan bermasyarakat tanpa tekanan dalam beribadah dan beraktivitas adalah harapan besar mereka bisa tercapai di kemudian hari nanti.

Harapan bahwa pemerintah Thailand akan memberikan kebebasan beragama dan beribadah pada muslim sebagai masyarakat pemeluk agama minoritas di negara mereka. Menghargai hak asasi setiap warganya untuk memeluk agama dan menjalankan kewajiban agama mereka tanpa harus memaksakan kehendak dengan merampas budaya dan kebebasan warganya, akan mengurangi konflik yang terjadi, sehingga kedamaian akan tercipta di seluruh wilayah di negeri Thailand. Harapan yang selalu akan muncul di setiap hati muslim minoritas Thailand.

Itulah gambaran mengenai apa yang dirasakan oleh muslim Pattani dari dulu hingga saat ini. Namun dewasa ini pemerintahan Thailand sudah mulai menunjuk petugas yang disebut dengan mufti sebagai penanggung jawab terhadap semua kegiatan muslim di Thailand. Salah satu bentuk sedikit keperdulian pemerintah Thailand terhadap muslim minoritas Pattani.

Harapan yang besar pula bagi muslim Pattani akan bisa mendapatkan kebebasan beragama dan saling menghormati antar 
agama akan terjalin di negara Thailand. Kebebasan beragama dan beribadah dan saling menghormati antar pemeluk agama seperti yang terwujud dengan Indonesia, juga terwujud di negara Thailand.

Semoga kedamaian akan tercipta di negara-negara dengan minoritas pemeluk suatu agama, apapun agamanya. Kedamaian tercipta di seluruh belahan dunia tanpa adanya diskriminasi dan penjajahan suatu pemeluk agama apapun agamanya.

Saling menghormati dan menghargai tanpa memaksakan kehendak untuk memeluk agama atau menerapkan budaya kepada pemeluk agama atau pemilik suatu budaya pada suatu komunitas masyarakat.

\section{KESIMPULAN}

Migrasi adalah perpindahan penduduk dari desa ke kota, atau perpindahan penduduk atau kelompok orang dari suatu wilayah ke wilayah lain baik dengan tujuan menetap atau tidak menetap.

Proses migrasi yang terjadi di suatu negara (International Migration) dianggap sebagai suatu hal yang alamiah sebagai kegiatan penyaluran tenaga kerja dari daerah di sektor kerja modern di wilayah kota yang daya serapnya lebih tinggi.

Faktor sosial-ekonomi yang rendah sehingga tidak mencukupi kebutuhan keluarga memotivasi seseorang ingin masuk ke daerah lain dengan tujuan memperbaiki kesejahteraan hidup nya dan kelurganya.

Faktor keamanan juga menjadi penyebab seseorang atau sekelompok orang melakukan migrasi. Daerah asal yang dirasa kurang menjamin keamanan dan kenyaman dalam aktivitas membuat munculnya kegiatan migrasi dengan tujuan mencari keamanan yang kebih baik di daerah tujuan.

Thailand adalah salah satu negara diantara negara-negara di kawasan Asia Tengara. Secara geografis, kawasan Asia Tenggara merupakan kawasan antara Benua Australia dan daratan China. Dengan letak geografis Thailand membuat negara yang dijuluki 
dengan Gajah Putih ini mudah dijangkau oleh para turis dari berbagai penjuru negara. Mayorits penduduk Thailand beragama Budha, sedikit yang beragama Islam dan Konghucu.

Pattani merupakan kerajaan terletak di sebelah selatan Thailand dengan penduduknya melayu dan dipimpin oleh seorang raja yang bernama Sulaiman. Kerajaan Siam waktu itu berusaha ingin menguasai Pattani dengan mengirimkan berulang kali pasukan untuk merebut wilayah Pattani, namun usaha nya selalu gagal.

Muslim Pattani berfaham bahwa mempertahankan dan melestarikan budaya Pattani adalah jihad keagamaan. Kebudayaan muslim Pattani berdasarkan hukum Islam.

Sementara pemerintah Thailand memberlakukan hukum sipil Thailand pada masyarakat Pattani. Hukum ini tentu saja menggeser hukum Islam yang diterapkan di Pattani. Namun dengan perjuangan yang panjang akhirnya diresmikan buku pedoman dalam hukum keluarga dan kewarisan Islam berlaku di wilayah propoinsi selatan yang meliputi Pattani, Narathiwat, Yala dan Satun.

Saat ini, kerajaan Thailand cukup mensupport kehidupan Islam untuk penduduknya. Seseorang yang di panggil Mufti adalah seseorang yang ditunjuk pemerintah di Thailand sebagai penanggung jawab masalah-masalah yang berhubungan dengan agama Islam di Thailand. Mufti mendapatkan gelar Syaikhul Islam (Chularajmontree). Mufti bekerja di bawah naungan Kementerian dalam negeri.

Suatu harapan baru muncul dari kebijakan baru pemerintah Thailand. Setitikcahaya muncul sebagai harapan bagi muslim Pattani untuk mendapatkan kedamaian, kenyaman dan kemerdekaan dalam menjalankan kehidupan beragama dan bermasyarakat di tanah Thailand.[] 


\section{DAFTAR PUSTAKA}

Junaidi, Faruq, Minoritas Muslim Thailand selatan, Artikel Ilmiah, t.t.

Krustiyati, Atik, Optimalisasi Perlindungan dan bantuan, Jurnal Dinamika Hukum Pekerja Migran Melalui Promosi Konvensi Pekerja Migran Tahun 2000, Vol. 13, No.1, januari 2013.

Kusuma, Bayu Mitha Adhyatama, Masyarakat Muslim Thailand dan Dampak psikologis Kebijakan asimilasi Budaya, Jurnal Hisbah,, Vol.13, No.1 Juni 2016.

Purnomo, Didit, Fenomena Migrasi Tenaga Kerja dan Perannya Bagi Pembangunan Daerah Asal: Studi Empiris di Kabupaten Wonogiri, Jurnal Ekonomi Pembangunan, Vol.10, No.1, Juni 2009.

Rina Rehayati, Minoritas muslim, Jurnal Ushuludin, Vol. XVII, No. 2, Juli 2011.

Sodiqin, Ali, Budaya Muslim Pattani Integrasi Konflik daan Dinamikanya, Jurnal Kebudayaan Islam, Vol.14, No.1 Januari-Juni 2016.

Soliah, Siti, Pola Migrasi Masyarakat, Jurnal Migrasi, FKIP, UMP, 2016.

Solikhin, Ahmad, Islam, Negara, Dan Perlindungan Hak-Hak Islam Minoritas, Journal Of Governance, Vol 1, No.2, Desember 2016

Wahib, Abdul, Pergulatan Pendidikan Agama Islam di Kawasan Minoritas Muslim, Jurrnal Walisongo, Vol.. 19, No.2, 2011.

Wayeeka, Niaripen, BerIslam dan Bernegara Bagi Muslim Patani: Perspektif Politik Profetik, Jurnal Agama dan hak Asasi Manusia, Vol. 5, No.2, Mei, 2016.

Yunianto, P. Rudolf, Lembaga Ilmu Pengetahuan Indonesia. t.t. 